\title{
Ownership Patterns of Palestinian Media and Its Influence on Media Policy
}

\author{
Dr. Amin Mansour Wafi ${ }^{1 *}$, Mr. Hussein M .F. AbouMddan ${ }^{2}$ \\ ${ }^{1}$ Associate Professor, the Head of Media and Journalism Department. Islamic University of Gaza \\ ${ }^{2}$ Researcher in Media Studies
}

*Corresponding Author: Dr. Amin Mansour Wafi, Associate Professor, the Head of Media and Journalism Department. Islamic University of Gaza

\begin{abstract}
The study aims to identify the patterns of ownership of Palestinian media, and the Influence of these patterns on the contents of the media policy, which is a descriptive study, and the survey studies approach was used, and within its framework the method of surveying media practices, as well as the method of studying correlational relations, and through it the method of systematic comparison, And the tool, the survey newspaper, and the study sample, the contact persons who hold administrative positions in the Palestinian media institutions, which number 123 respondents. And it works to direct it according to its goals, and there are positive and negative effects of advertisements that are reflected on the media policy of the media institution, and among the most important recommendations is the enactment of a law that regulates the relationship between the owners of the media institution, and their relationship with media policy makers, encouraging investment in media institutions, with the need to diversify financial resources.
\end{abstract}

Keywords: Ownership - Media Institutions - Media Policy - Contact Perso.

\section{INTRODUCTION}

The media has become one of the important industries in developed countries due to the huge capital invested in the diverse and numerous fields of media, and according to experts, the media is considered the third largest industry in the world after the manufacture of weapons and chemicals, and this industry has played a role in shaping the economy, politics, religion and society's culture at the present time. . The media is considered an investment in knowledge, in a world that witnesses an information revolution every day in various fields, where different media have witnessed tangible changes in their ownership patterns, management, organizational structures, sources of financing and production techniques in light of these rapid changes, and these changes were reflected in media institutions, which made adjustments. Fundamental to its media, administrative and economic policy, and as a result of the developments brought about by the technological revolution, the forms of ownership and methods of media management diversified, as it brought about a clear change in the network of social relations and the prevailing pattern of control, and contributed to the creation of the decentralized style of management and the trend towards integrative management in which the lines of ownership, management and responsibility go. Vertically and horizontally at the same time and in more than one direction. The issue of the relationship between the ownership pattern in the Western media system and the media policy of the media is one of the issues raised in the agenda of Western media research. Ralf Thrift (1977) is considered one of the first Western media researchers to research this issue, and it was preceded by references to it by some researchers, as a reaction to the dramatic shift in media ownership there since the beginning of the sixties of the twentieth century, but in-depth studies of this The case has been delayed for some time until the phenomenon is completed and crystallized.

With the increasing interest in investing in the field of media, and the transformation of media ownership into the pattern of chains, major monopolies and the ensuing increase in monopoly and concentration in media ownership, this was reflected in the changes in the trends, contents and media policies resulting from this transformation.

Therefore, this study came to identify the extent of the reflection of the ownership pattern and the party financing it on the media policy, in addition to identifying the positive and negative effects of 
each type of ownership, and the effect of this on the contact persons in Palestinian media institutions, and to know the most appropriate properties of Palestinian media institutions, and to identify problems And the danger of private property.

The first topic: The general framework of the study: First: The most important previous studies: The Bushra study (2017 CE) came: to reach laying foundations for the editorial policy of the radio (Omdurman National Radio) and address its obstacles and work on broadcasting the news without blackouting it in order to enhance the trust between the recipient and the radio, and you belong This study is based on descriptive research, and the method used for the media survey, and the tool used the content analysis form, to analyze the most important forms of news selected in the radio in question, and the survey form for experts and workers in news production, and it relied on the theory of the gatekeeper. The most important results: $83 \%$ of the respondents, who fully agree, believe that the editorial policy of the radio station is based on the state's media strategy, and 17\% agree. Ibrahim's study (2016 AD) showed the impact of press advertisements on the editorial policy of daily newspapers, and learning about the ethics of the media profession. Attention and independent "", and the theory of priority order was used, and among the most important results $90 \%$ of the respondents, who are completely in agreement, believe that the Sudanese press devotes the front page to advertisements more than it is interested in editorial material. 2014 AD) the editorial policies of the Gulf press and the factors affecting the communicator, especially in light of technological progress, and the study belongs to descriptive research, using the method of media survey, and the questionnaire as a tool for data collection. The study population was represented in a sample of journalists and the most important results: $81 \%$ of the respondents believe that the most prominent problems prevailing among journalists are related to low financial returns and dealing with reliable sources, that Gulf newspapers adhere to the official policy orientations of the countries of the Cooperation Council for the Arab Gulf States, and the study of Al-Fatafta (2013 AD) showed Media Policies in Palestine and Editorial Policy in Daily Newspapers (Al-Quds, Al-Hayat, Al-Ayyam, Palestine) This study belongs to descriptive research, using the method of media survey, and the study relied on focused interviews and wide dialogues with many journalists and editors, and its theory is the order of priorities. Among the most important results: the editorial policy of the newspaper is subject to a number of influences that in its entirety constitute the image and essence of this policy These influences are represented in the following: the personality of the editor, the distinct character of the newspaper, the readers 'needs, funding the newspaper, social pressures, press laws, national loyalty, the newspaper's journal. AlShujairi's study (2012 CE) clarified: The sources of funding for newspapers are according to what those responsible for them announce, and its reflection on its policy, and the size of the reflection of funding on the editorial policy of the Newspaper, diagnosing the role of funding in changing the contents of the editorial policy, and revealing the role of the funder in drawing, planning and defining the editorial policy. It is a descriptive study, using the media survey method, and a questionnaire as a tool to collect data. The study population was represented in the newspaper workers of the study sample, whose number is 63 individuals, who are of a degree (Editor-in-Chief, Deputy Editor, Editorin-Chief, Editor-in-Chief, Heads of Departments). The sample is based on different funding sources according to the respondents' answers with government support, or a person or a party in exchange for relying on advertisements and selling press services as an important source for the continuity of the newspaper's publication, and emphasizing the funding agency's control of editorial politics. Abdul Rahman's study (2011AD) came to clarify the relationship between ownership of media The media and its treatment of the issues of democratization and political decision-making and the search for the reasons for this role, if any; And then directing attention to rebuilding the structure of the media, which is a descriptive study. It used the survey method, and relied on the content analysis form as a tool to collect data from the newspapers under study (Al-Wafd newspaper, Al-Shorouk newspaper, and two channels: ON TV and CBC. " The survey questionnaire and among the most important results: The media outlets are affected by the interests of their owners when dealing with the issues of democratization under study. The organization of newspapers and their editorial policies, through the use of the historical method, monitoring the relationship of the press to the authority and the existing systems of government, which is a descriptive study, and it used the historical method. Newspapers, and among the most important results: Most types of newspapers are related to political parties and the existing system, and that a large segment of them are linked to broad interests relations with the ruling political system, and the study of Cohen and McDow NALAD (M. 2011): The impact of economic 
and technological challenges and pressures on the management of a number of press and media projects in Canada towards the "public service media" pattern, which is a descriptive study, and the survey method was used. The survey newspaper and personal interviews were used as a tool to collect data from those in contact In the most famous Canadian newspapers, and among the most important results: Many press enterprises and institutions that are not related to monopolies and commercial investments have begun to face fierce competition from the newspapers of chains and monopolies, many newspapers and radio stations have stopped; This prompted the concerned researchers, media planners, trade unions and their unions to adopt the model of public service media. The study of Pickard and Wiesel (2011 AD) showed: The most important implications and results associated with the terrible shifts in the patterns of ownership of different newspapers, and the effect of these patterns of ownership on newspaper management methods, methods of organization and policies, which is a descriptive study and used the survey method. The study relied on the latest findings of researchers regarding The repercussions related to newspaper ownership and its reflection on the management and policy of these newspapers around the world, and among the most important results: There is a great agreement among researchers that there is no such thing as an optimal ownership pattern that enjoys the agreement and acceptance of all. Expanding the ownership base, as in the projects owned by chains, increases control and centralization In decision-making, unlike in the case of newspapers owned by individuals or non-profit enterprises. Wilson's study (2010 AD) showed: The methods used by newspaper owners and shareholders in organizing and managing all aspects of journalistic work in the institutions they own, and the mechanisms for controlling newspapers within the framework of their general orientations and interests. It is a descriptive study, and it used the survey method. The study was applied to three of The largest press organization "Kalamar - Boras - Sundsvall", using an in-depth interview method with a number of editorial and administrative leaders responsible for managing newspapers, to learn about the most important methods of organization and control used by the owners. Among the most important results is that the pattern of newspaper ownership in Sweden has been dominated by the individual ownership pattern for many years and decades, directing journalistic projects towards adopting bureaucratic methods at work, and increasing the introduction of central and authoritarian concepts in management, which ultimately affects the independence of editorial decision and job satisfaction of editors. The study of Al-Yafei (2010 AD) clarified: patterns of ownership of Yemeni newspapers and the identification of factors affecting the building of their agenda, and the influence of political forces on this agenda. It is a descriptive study that used the survey method and the content analysis form tool as a tool to collect data and the sample number reached 80 respondents. I applied the agenda-building theory. Among the most important results: the existence of a difference between newspapers with regard to their agenda in dealing with societal issues and problems, according to the difference in the newspaper's ownership pattern and its political affiliation, and the existence of a correlation between the news values that newspapers deal with in their contents, and the pattern of ownership of each newspaper, indicating that newspapers Officials use the value of "state reputation", while partisan and private newspapers use the value of "institution reputation." The study of Poor and Anne (2009) showed: the conditions of some major press chains and groups in American society, such as the New York Times, Los Angeles Times, and Dallas Morning News groups; To get acquainted with its administrative and organizational conditions, working methods and directions, which is a descriptive study, and it used the survey method and the content analysis form as a tool for data collection. Among the most important results: the newspapers of the major chains tend to be associated with projects and commercial and economic investments that secure their economic influence, and work according to market requirements and mechanisms and not according to standards and requirements Professionalism and the spring study (2008 AD) showed: the relationship between the pattern of ownership of Egyptian newspapers (national or private) and the freedom to express opinion and come up with accurate data and information about the nature of this relationship, which is a descriptive study, and the survey method was used in choosing the variable of ownership pattern, with the constancy of a group of The variables are represented in the opinion materials published in the study newspapers and the field study community swallowed the number of 400 items, and the analytical sample from the source sample represented in the Al-Ahram morning daily newspaper, Rose Al-Youssef newspaper, Al-Masry Al-Youm newspaper, and Al-Dustour newspaper. And the content sample represented in all press formats for opinion articles. Among the most important results: the existence of a relationship between the pattern of newspaper ownership and 
the extent to which the issues addressed are related to the interests and interests of the readers, which was confirmed by the field study. Political systems combine ownership and management of newspapers, and even in cases where individuals are allowed to own newspapers, most of them are direct supporters. Or indirectly to the government. Abd al-Atti's study (2006 CE) clarified: The extent to which the form and content of the newsletter is affected by the ownership pattern in specialized Arab satellite channels, as well as to identify the form and content of media treatment, and whether it differs in the governmental pattern from the special pattern of the specialized satellite channels, namely A descriptive study, the survey approach and the content analysis form were used as a tool to collect data, and 60 news bulletins were analyzed with 30 bulletins per channel during the period, and among the most important results: the interest of government channels in local news coverage that falls within the scope of the state or the channel's owner, the interest of the channels Government news that holds one point of view, where the rate was $32.95 \%$, and the reason for this may be due to the increase in official and protocol news. Official officials showed the study of Lacey and Alice (1996 AD): the shift in journalistic ownership patterns in the United States, the increase in the trend towards concentration of ownership and major monopolies, and how the interest in increasing the gains and profits of the newspapers of the major chains at the expense of the press service and the social responsibility of newspapers towards the reader and society. It is a descriptive study, and it used the survey method. The questionnaire was used as a tool to collect data. It was distributed to a sample of 133 individual subjects applied to a sample of newspaper directors belonging to the Gannet Comp chains. - Knight Ridder - New York) (Times Comp. Among the most important results: the growth of chains and journalistic monopolies and the associated separation between ownership and management, and the weakness of supervision and control by owners over these projects led to an increase in interest in profits and profits at the expense of the press service. The press in the United States, according to the pattern of large companies, has made the issue of maximizing benefits and profits in the short term a major goal for managers of these projects, as it is a necessary goal for newspapers to remain under the system of major monopolies. Professional managers seek to maximize profits at the expense of important issues and goals such as Journalistic product quality, managing economics ethically, as opposed to owner-managers' results.

Second: The problem of the study: The problem of the study is to identify the patterns of ownership of Palestinian media institutions, and to identify the nature of the reflection of this pattern on the contents of the media policy, the extent of the influence of capital owners on the contents of the press arts and the pressures exerted by the funding bodies to influence the communicators and media policy, and the area of The freedom of expression granted to the institution in terms of funding, and the extent of its implications and suitability on the continuation of survival and permanence, and the most important problems, proposals and solutions for the survival and continuity of media institutions.

\section{Third: The importance of the study:}

1. Enriching the scientific library that lacks such specialized studies in researching the relationship between the pattern of ownership of media institutions and the extent of their reflection on media policy.

2. This study provides a perception of the extent to which the pattern of ownership of media institutions and their funding bodies reflects their media policy.

3. Knowing the margin of criticism and freedom that the communicator enjoys in the Palestinian media.

4. The importance of the study stems from the societal aspect, as it sheds light on the ownership of the media and its media policy.

Fourth: The objectives and questions of the study: The study seeks to achieve a major goal, which is to know the patterns of ownership of Palestinian media institutions, and the nature of the reflection of this pattern on the contents of the media policy, and this goal is divided into a group of the following sub-questions:

1. What is the nature of media policy in Palestinian media institutions?

2. What are the factors affecting the media policies of Palestinian media institutions? 
3. What is the ownership pattern in Palestinian media institutions?

4. What is the impact of ownership on media policy in Palestinian media institutions?

5. To what extent does the ownership pattern contribute to changing the contents of media policy in Palestinian media institutions?

6. What is the role that the funding bodies play in designing, planning and defining the media policy in Palestinian media institutions?

7. What is the most appropriate type of ownership pattern for media institutions from the point of view of communicators in Palestinian media institutions?

8. What are the levels of angel interference in the media policy of Palestinian media institutions?

9. What are the positive and negative effects of each type of ownership in Palestinian media institutions?

10. What are the positive and negative impacts of the returns generated by the commercial, advertising and investment activities practiced by some Palestinian media institutions?

11. What are the most important problems facing Palestinian media work resulting from the pattern of ownership, and what are the proposals to avoid them in Palestinian media institutions?

Fifth: The theoretical framework of the study: The study was based on the literature of the gatekeeper contact theory, which shows the various factors that affect the work of contact persons in Palestinian media organizations and the pressures they are exposed to as a result of the media policy of media institutions and the different types of ownership that are reflected in performance and freedom of expression.

\section{Sixth: Type of study, methodology and tool:}

1. Type of study: This study is part of descriptive research aimed at photographing, analyzing and evaluating the characteristics of a particular group or situation that predominates in the characteristic of identification, in addition to estimating the number of times the occurrence of a certain phenomenon, and the extent of its relationship to another phenomenon or group of phenomena.

2. Study methodology: The two researchers relied in their studies on the following Approaches:

1. Survey Studies approch: It is an organized scientific effort to obtain data, information and descriptions of the phenomenon or group of phenomena under consideration. It aims to record, analyze and interpret the phenomenon in its current state after collecting the necessary data and adequacy on it and its elements through a set of organized procedures that determine the type of data, its source and methods Obtained . Within the framework of this approach, the study used: The method of surveying media practices: which is to "study the aspects, methods and organization of the media and its management in various media fields, with the aim of depicting the applied reality, and identifying the methods followed by these agencies in the exercise of their various activities.

2. The correlational relationship study approach: It aims to identify the relationships between the different variables in the phenomenon or group of phenomena under study. This type of curriculum is suitable for this study because it is useful in studying the relationship between two or more phenomena, and enables the answer to the study's questions, such as knowing whether there is a correlation Two or more variables in the phenomenon, and the nature of this relationship in terms of whether it is direct or inverse, and this approach also allows to know the degree of this correlation between the variables and their severity. The ownership pattern of each newspaper, its sources of funding, and the size of a reflection on corporate ownership and media policy.

3. . The study tool: The survey sheet was used: It is "one of the basic methods that are used to collect primary, basic or direct data from the selected sample or from all research vocabulary by directing a set of specific questions prepared in advance, with the aim of identifying certain facts, Or the viewpoints of the respondents and their attitudes, or the motives, factors and influences that push them to certain behaviours, "by monitoring and analysing the vision of the communicators regarding the reflection of the pattern of ownership of their media institutions on their media 
policy. A questionnaire was prepared on "Patterns of Palestinian Media Ownership and Their Reflection on Media Policy - A Study on the Contact Person", and it consists of five main axes:

1. The first axis: which is about personal and general features

2. The second axis: ownership of media institutions, their types and patterns.

3. The third axis: the concept of media policy, its objectives, and the factors affecting it.

4. The fourth axis: advertising revenue in institutions and their relationship to media policy.

5. Fifth Axis: Obstacles and Proposals.

\section{Seventh: Study population and sample:}

1. The study population: The study population is represented by the communicators who work in the various official, partisan and private Palestinian media institutions, who are the highest administrative level in the institution up to a minimum editor, provided that the contact person is from the following categories (editor-in-chief, editor-in-chief, Editorial secretary, program director, department head, editor, director, reporter, photographer), and these groups we believe are the most capable of determining the size of the influence of ownership style on media policy.

2. The study sample: Considering the difficulty in determining the number of the study sample and the size of the sample, and the difficulty of communicating with all its items, especially those in the West Bank and Jerusalem. The available sample was chosen from workers in electronic and printed press institutions from the following categories (editor, Reporter, Head of the Department, Director, Photographer, Editorial director, Secretary edit, chief editor) the total is 123 items.

Table1. Showing the personal characteristics

\begin{tabular}{|l|lr|ll|}
\hline Gender & Number & Percentage\% & 73.2 \\
\hline Male & & 90 & & 26.8 \\
\hline Female & & 33 & & \\
\hline Total & 123 & 100 & \\
\hline
\end{tabular}

\begin{tabular}{|c|c|c|}
\hline Place of living & Number & Percentage\% \\
\hline Gaza strip & 78 & 63.4 \\
\hline West Bank & 45 & 36.6 \\
\hline Total & 123 & 100 \\
\hline Age & Number & Percentage\% \\
\hline 25 to less 35 years & 66 & 53.7 \\
\hline 35 to less 45 years & 25 & 20.3 \\
\hline 45 years and more & 19 & 15.4 \\
\hline Less to 25 years & 13 & 10.6 \\
\hline Total & 123 & .100 \\
\hline Years of experience & Number & Percentage \% \\
\hline 5 to less 10 years & 40 & 32.5 \\
\hline 10 less to 15 years & 32 & 26.0 \\
\hline 15 years and more & 27 & 22.0 \\
\hline Less 5 years & 24 & 19.5 \\
\hline Total & 123 & 100 \\
\hline The position occupied by the contact person & Number & Percentage\% \\
\hline Editor & 52 & 42.3 \\
\hline Reporter & 23 & 18.7 \\
\hline Head of the Department & 17 & 13.8 \\
\hline Director & 9 & 7.3 \\
\hline Photographer & 6 & 4.8 \\
\hline Editorial director & 5 & 4.1 \\
\hline Secretary edit & 4 & 3.3 \\
\hline Other & 4 & 3.3 \\
\hline Chief Editor & 3 & 2.4 \\
\hline Total & 123 & 100 \\
\hline Work system in the media institute & Number & Percentage\% \\
\hline Permanent contract & 73 & 59.3 \\
\hline
\end{tabular}




\begin{tabular}{|l|r|r|}
\hline Annual contract & 42 & 34.2 \\
\hline Reward & 8 & 6.5 \\
\hline Total & $\mathbf{1 2 3}$ & $\mathbf{1 0 0}$ \\
\hline Specialization & 102 & Percentage\% \\
\hline Media & 21 & 82.9 \\
\hline Another specialty & Number & 17.1 \\
\hline Total & $\mathbf{1 2 3}$ & $\mathbf{1 0 0}$ \\
\hline
\end{tabular}

$* * * \mathbf{N}=123 * * *$

1. Gender: It was found from the previous table that $73.2 \%$ of the study sample were male contacts, and $26.8 \%$ were females.

2. Age: From the previous table it was found that $53.7 \%$ are those from 25 years old to less than 35 years old, $20.3 \%$ are those from 35 years old to less than 45 years old, and $15.4 \%$ are those whose age is 45 years and over, $10.6 \%$ of the study sample were less than 25 years old.

3. Place of residence: It is evident from the above table that $63.4 \%$ of the study sample are those residing in the governorates of the Gaza Strip, and 36.6\% are those residing in the West Bank.

4. Years of Experience: It was found from the previous table that $32.5 \%$ are those with years of experience from 5 years to less than 10 years, and $26.0 \%$ are those with years of experience from 10 years to less than 15 years, and a rate of $22.0 \%$ Those who have 15 years of experience or more, $19.5 \%$ of the study sample are those with less than 5 years of experience.

5. The position occupied by the contact person: it is clear from the previous table that $42.3 \%$ of the study sample are editors, $18.7 \%$ are correspondents, $13.8 \%$ are department heads, $7.3 \%$ are directors, and $4.8 \%$ are directors. \% Are photographers, $4.1 \%$ are editor-in-chief, $3.3 \%$ are from the editorial secretariat, $3.3 \%$ are from other jobs, and $2.4 \%$ are editors-in-chief.

6. The system of work in the media institution: It was found from the previous table that $59.3 \%$ of the study sample work on permanent contracts, $34.2 \%$ work on annual contracts, and $6.5 \%$ work with the reward and incentive system.

7. Academic qualification: It was found from the previous table that $82.9 \%$ of the study sample are in the field of media, and $17.1 \%$ are from other disciplines.

8. The researchers believe that these results are logical, as press institutions have specificities in Palestine that may differ from other regions due to the challenges that society faces.

3. Validity of the questionnaire: the validity of the questionnaire means: "that the questionnaire measures what it was set to measure." He also means "The survey's inclusion of all the elements that should be included in the analysis on the one hand, and the clarity of its paragraphs and vocabulary on the other hand, so that they are understandable to everyone. Uses it, and the validity of the questionnaire was verified through "apparent truthfulness": what is meant by the veracity of the arbitrators: "The two researchers choose a number of arbitrators specialized in the field of the phenomenon or problem that is the subject of the study" (Al-Jarjawi, 2010 AD, Page 107), where the questionnaire was presented to a group of referees, consisting of (7) specialists in the field of media, and the two researchers responded to the opinions of the referees, and they made the necessary deletions, additions and amendments in light of the proposals submitted, until the questionnaire came out in its final form.).

Eighth: The statistical methods used: The analysis was carried out by the Statistical Package for the Social Sciences (SPSS).

The following statistical tools were used:

1. Frequencies \& Percentages: to describe the study sample.

2. means, the relative weight, and the standard deviation.

\section{Ninth: Terms of the study:}

First: Ownership: The definition of Ownership idiomatically: The jurists used the term "Ownership" more than the term "property" in most of their books, as it was the most common one for them considering that the property is the one who revolves around the possession and ownership of 
something, while the term "ownership" expresses the relationship of ownership In itself, that is, as an adjective that joins the owner and the thing owned together, and it was used by later scholars.

* Ownership in media studies: Ownership is one of the pillars of the media system, rather it basically represents the form and nature of the system, and the forms of media ownership vary and differ according to the different media system to which they belong. Muhammad Syed Muhammad says: (newspaper ownership is an expression of freedom of the press, and both are An expression of the media theory prevalent in a society, and a reflection of the political system with its various pillars, economic, cultural, social, and so on. Therefore, we must refer to media theories to reveal the true dimensions of the relationship between newspaper ownership and freedom of the press. The two researchers define ownership: it is the power owned by an individual or group of individuals over a certain thing, whereby that individual or group will be able to exercise their rights to adapt this thing as they want, based on the rights arising from that ownership and power. From a media point of view, it can be defined as the entity that owns that media outlet, whether it is government or private, as that owner has the freedom to formulate the policies of that media.

Second: Media policy: The media policy is defined as a set of principles, rules and broad lines that control the method or way in which media content is presented. For daily media work, it is subject to a great deal of flexibility, the degree of which varies from one medium to another, from one situation to another, and from one period to another within the same medium. The two researchers define the media policy: it is the pattern or method by which the media outlet draws and outputs all that is issued by it in terms of saying, action or report. It works in that medium by adhering to these principles and goals.

The second topic: Field study results and recommendations: This topic reviews the general results of the field study and discusses them, in order to identify the reality of the patterns of ownership of Palestinian media institutions and their reflection on media policy. The first requirement: discussing the results of the field study.

\section{The approved study criterion:}

\begin{tabular}{|l|l|l|}
\hline Cell length & Corresponding relative weight & Degree of approval \\
\hline From $1-1.80$ & From $20 \%-36 \%$ & Very few \\
\hline Greater than- 1.80-2.60 & Greater than $36 \%-52 \%$ & Few \\
\hline Greater than 2.60-3.40 & Greater than $52 \%-68 \%$ & Medium \\
\hline Greater than $3.40-4.20$ & Greater than $68 \%-84 \%$ & large \\
\hline Greater than $4.20-5$ & Greater than $84 \%-100 \%$ & Very large \\
\hline
\end{tabular}

\section{First: the ownership of media institutions}

\section{Type of ownership of the institution:}

Table2. Shows the type of newspaper ownership of study newspapers:

\begin{tabular}{|l|r|r|r|}
\hline Ownership of the media institution & \multicolumn{1}{|l|}{ Number } & Persentage\% & Arrangement \\
\hline Institute & 43 & 35.0 & 1 \\
\hline Political movement & 33 & 26.8 & 2 \\
\hline Country & 23 & 18.7 & 3 \\
\hline Person & 15 & 12.2 & 4 \\
\hline a commercial company & 7 & 5.7 & 5 \\
\hline Other & 2 & 1.6 & 6 \\
\hline Total & $\mathbf{1 2 3}$ & $\mathbf{1 0 0 . 0}$ & \\
\hline
\end{tabular}

It was found from the previous table that $35.0 \%$ of the study sample work in media institutions of an institutional ownership nature, $26.8 \%$ in political movement ownership, $18.7 \%$ state ownership, $12.2 \%$ individual ownership, and $5.7 \%$ Ownership of a commercial company, and $1.6 \%$ of media institutions with other ownership. The researchers believe that this multiplicity and difference in the type of ownership of Palestinian media institutions is a product of the current Palestinian situation, as there are many types of ownership belonging to private institutions or movement. These results are consistent with the conclusion of the study of Pickard and Wiesel (2011), which found great agreement among the respondents that there is no such thing as a single ownership type. It also agrees with the study of Adesuji and Han (2011) that the majority of types of media institutions are linked to political parties and the existing system, and that a large segment of them are linked to broad interest relations with the regime. 


\section{Form of ownership:}

Table3. Shows the appropriate form of ownership according to the respondents:

\begin{tabular}{|l|r|r|r|}
\hline The form of ownership of the institution & Number & Percentage\% & Arrangement \\
\hline Contributed company & 72 & 58.5 & 1 \\
\hline Holding & 21 & 17.1 & 2 \\
\hline Individual & 10 & 8.1 & 3 \\
\hline Limited liability company & 9 & 7.3 & 4 \\
\hline Governmental & 6 & 4.9 & 5 \\
\hline Cooperative & 5 & 4.1 & 6 \\
\hline Total & 123 & 100 & \\
\hline
\end{tabular}

It is evident from the previous table that $58.5 \%$ of the study sample prefer the form of the Contributed company to own the media institution, and $17.1 \%$ prefer the form of the holding company, $8.1 \%$ prefer the individual ownership form, and $7.3 \%$ prefer the limited liability company, and what is its percentage $4.9 \%$ prefer the government form of ownership of the newspaper, and $4.1 \%$ prefer the cooperative company. The previous results show that the largest number of media professionals prefer that the institution be owned by a Contributed company, and to move away from government ownership due to the dependencies it carries on media work.

The researchers attribute this to the professional and administrative pressures that media workers working in government institutions are subjected to that limit their work. They also believe that jointstock companies give them a margin of freedom, as they are part of the decision-making in those institutions. This result is consistent with the findings of Abdul Rahman's study (2011 AD), which found that the media are affected by the interests of their owners. Therefore, journalists try to get out of this influence by working in newspapers belonging to Contributed companies.

\section{Conditions for the owner of the press institution:}

Table4. Clarifies the necessary conditions that must be met by the owner of a press institution:

\begin{tabular}{|c|c|c|c|}
\hline $\begin{array}{l}\text { The necessary conditions that must be met by } \\
\text { the owner of the institution }\end{array}$ & Nnumber & Percentage \% & Arrangement \\
\hline To be professional & 118 & 95.9 & 1 \\
\hline He has knowledge of the media industry & 94 & 76.4 & 2 \\
\hline Familiar with media work & 93 & 75.6 & 3 \\
\hline He holds an academic degree in media & 87 & 70.7 & 4 \\
\hline Other & 17 & 13.8 & 5 \\
\hline Total & 409 & & \\
\hline
\end{tabular}

- Multiple choice answers have been calculated from 123

It was found from the previous table that $38.9 \%$ of the study sample believe that the necessary conditions that must be met by the owner of the media institution are to be a professional, and $76.4 \%$ to have knowledge of the media industry, and $75.6 \%$ believe that he should be familiar with the work of the media, and what is its percentage $70.7 \%$ that the owner of the institution holds an academic degree in media. The two researchers believe that there is an agreement among media workers about the conditions that must be met by the owner of the institution, so that he is a professional in his work and is familiar with the various aspects of the institution's work, whether these aspects are related to the administrative or institutional work of the institution or the legal aspects and ethics of the profession.

\section{The form of intervention of the owners of institutions:}

\begin{tabular}{|c|c|c|c|c|}
\hline $\begin{array}{l}\text { The form of intervention of } \\
\text { the owners of the } \\
\text { institutions that are } \\
\text { implemented in the media } \\
\text { policy }\end{array}$ & SMA & $\begin{array}{l}\text { Standard } \\
\text { deviation }\end{array}$ & Relative weight & Arrangement \\
\hline $\begin{array}{l}\text { The owner only sets general } \\
\text { guidelines and principles } \\
\text { that cannot be crossed. }\end{array}$ & 3.87 & 0.634 & 77.40 & 1 \\
\hline The owner outlines a media & 3.83 & 0.881 & 76.60 & 2 \\
\hline
\end{tabular}




\begin{tabular}{|c|c|c|c|c|}
\hline $\begin{array}{l}\text { policy and makes it binding } \\
\text { on the editors. }\end{array}$ & & & & \\
\hline $\begin{array}{l}\text { The owner participates in } \\
\text { managing the editorial } \\
\text { policy. }\end{array}$ & 3.81 & 0.657 & 76.20 & 3 \\
\hline $\begin{array}{l}\text { Preserving the interests of } \\
\text { some political parties and } \\
\text { bodies }\end{array}$ & 3.44 & 0.779 & 68.80 & 4 \\
\hline $\begin{array}{l}\text { The ideological character of } \\
\text { the institution }\end{array}$ & 3.43 & 0.736 & 68.60 & 5 \\
\hline $\begin{array}{l}\text { Protection of some } \\
\text { associations and institutions }\end{array}$ & 3.35 & 0.831 & 67.00 & 6 \\
\hline $\begin{array}{l}\text { The power of the } \\
\text { movements and the political } \\
\text { system. }\end{array}$ & 3.28 & 0.927 & 65.60 & 7 \\
\hline $\begin{array}{l}\text { The power of capital on } \\
\text { media policy. }\end{array}$ & 3.16 & 0.986 & 63.20 & 8 \\
\hline $\begin{array}{l}\text { The owner does not } \\
\text { interfere in the media } \\
\text { decision-making at all. }\end{array}$ & 3.08 & 0.795 & 61.60 & 9 \\
\hline 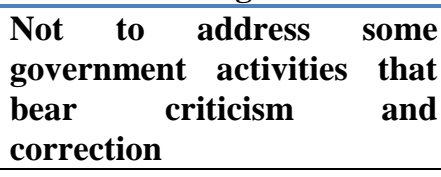 & 2.94 & 0.899 & 58.80 & 10 \\
\hline
\end{tabular}

Table5. Shows the form of interference by corporate owners in media policy:

It is evident from the previous table that Paragraph No. (1) which stipulates "The owner specifies only general lines and principles that cannot be crossed" ranked first with a relative weight (77.40\%), which indicates that he has obtained a (large) degree of approval by individuals. The researchers attribute that to the fact that the owner of the institution considers himself the only one who sets the broad lines of work within the media institution, and the media professionals must implement these lines without the slightest change, and this applies to most of the owners of Palestinian media institutions. That it be a hindrance to media work, as the journalist who works in the institution remains threatened with accountability if he strives outside these lines, and the media policy of the institution remains dependent on the dictates of the owner, whether it is a state, political party or individuals, and this result is consistent with what Abdul Rahman's study found. (2011 AD), as it stated that the media are affected by the interests of their owners when dealing with various issues .It also agrees with Wilson's study (2010), as it stated that media projects are directed towards adopting bureaucratic methods at work, and increasing the introduction of central and authoritarian concepts in management, which ultimately affects the independence of media decision and job satisfaction for editors.

\section{Type of funding: Table (6): shows the type of funding that the media institution depends on:}

\begin{tabular}{|l|r|r|r|}
\hline The type of funding the press organization depends on & Number & Percentage \% & arrangement \\
\hline Advertising and marketing & 63 & 51.2 & 1 \\
\hline Self-funding & 57 & 46.3 & 2 \\
\hline Party support & 39 & 31.7 & 3 \\
\hline Governmental support & 25 & 20.3 & 4 \\
\hline Total & 418 & & \\
\hline
\end{tabular}

\section{- Multiple choice answers have been calculated from 123}

It was found from the previous table that $51.2 \%$ of the study sample depends on advertising and marketing funding, $46.3 \%$ of self-funding $31.7 \%$ of party and organizational support, and $20.3 \%$ of government support. The researchers attribute this to the fact that most media institutions are not owned by the state or movements, and that they are private institutions that seek to achieve material profit in order to cover their funding through advertising and marketing, and this makes the media institution in line, directly or indirectly, with the goals and policies of its advertisers, and not to go into all What could disturb these advertisers and marketers. We also see that self-support for media institutions provides a space of freedom in which media policy makers can work more professionally, 
and reach the main goal of media work that works to serve society, by raising various issues that affect the interests of society in full transparency and neutrality. It is noted that many media institutions depend on party funding, and this is a natural thing, as many media institutions operating in Palestine explicitly and explicitly belong to Palestinian parties such as the Resala Foundation and the Al-Aqsa Media Network, as they are owned by the Islamic Resistance Movement, Hamas, and the Independence Foundation is owned by the Islamic Jihad Movement. There are also institutions that receive their support from the authority or the government, such as the New Life Foundation, which receives its support from the Palestinian Authority, the Radio and Television Corporation, and some websites and local radio stations. The results are consistent with Ibrahim's study (2016), where he stated that $(90 \%)$ of the respondents believe that the Sudanese press devotes the front page to advertisements more than it is concerned with editorial material.

\section{Financial support:}

Table (7): shows the frequency and percentage of knowledge of the study sample for financial support agencies:

\begin{tabular}{|l|r|r|r|}
\hline Financial support from various quarters & Number & Percentage \% & arrangement \\
\hline I don't know the support points. & 63 & 51.2 & 1 \\
\hline I have no opinion. & 54 & 43.9 & 2 \\
\hline Yes familiar with the support points. & 6 & 4.9 & 3 \\
\hline Total & 123 & & \\
\hline
\end{tabular}

It was found from the previous table that $51.2 \%$ of the study sample do not know whether the media institution in which they work obtains financial support from different parties, and $43.9 \%$ assert that the institution in which they work does not obtain financial support from different parties, and what percentage $4.9 \%$ agree that their institution receives support from donor agencies. The researchers attribute the previous result to the fact that many workers in media institutions do not care about the sources of support, but are concerned that the media institution provides their salaries at the end of each month, and they do not participate in setting the financial policies of the media organization and directly see the revenues and expenses that the institution achieves. As for those who deny that the media institution receives financial support from various parties, then of course these institutions are owned by the state or the ruling regime, and therefore he is spending on them and considers his voice to the masses. There are media institutions owned by the various parties, which are considered part of the party's institutions and the mouth of its condition. Those who work in these institutions belong to the party and its members and receive their salaries from their party.

\section{Second: The concept of editorial policy, its objectives, and the factors affecting it:}

\section{The concept of the newspaper's editorial policy:}

Table8. Clarifies the concept of the newspaper's editorial policy:

\begin{tabular}{|l|r|r|r|}
\hline The concept of editorial policy & Number & Percentage \% & arrangement \\
\hline $\begin{array}{l}\text { It is a set of principles, rules and guidelines that } \\
\text { govern the style and manner in which media content } \\
\text { is presented }\end{array}$ & 44 & 35.8 & \\
\hline $\begin{array}{l}\text { Is the destination that the institution chooses to follow } \\
\text { in its answers to two questions: What will it publish? } \\
\text { How will it be published? }\end{array}$ & 43 & 35.0 & \\
\hline $\begin{array}{l}\text { It is a reflection of the views of the owners, the } \\
\text { editors, the trends of the prevailing political, } \\
\text { economic and social systems, on the media content, } \\
\text { its orientations and methods of presenting it in a way } \\
\text { that leads to the achievement of the goals of the } \\
\text { owner, the media institution, the goals of society }\end{array}$ & 36 & 29.2 & \\
\hline Total & & & \\
\hline
\end{tabular}

It was found from the previous table that $35.8 \%$ of the study sample believe that the concept of media policy they have is a set of principles, rules and guidelines that control the style and the way in which media content is presented, and 35\% of their concept is summarized by them as the destination that chooses the media institution Followed her in her answers to two questions: What will you publish? 
How will it be published ?, and what $29.2 \%$ see it as a reflection of the views of the owners, the editors, and the trends of the prevailing political, economic and social systems, on the media content, trends and methods of presenting it in a way that leads to achieving the goals of the owner, the media institution, and the goals of society. It is noticeable that there is a convergence between the percentages of the respondents in their answers about their concept of the media policy of the institution in which they work, whether this policy is a set of principles, rules and guidelines that control the style and the way in which the media content is presented, or it is the destination that the institution chooses to follow in Its answers to two questions: What will you post? How will it be published? Or, is it the product of the owners' and editors 'visions and the trends of the prevailing political, economic and social systems on the media content and its trends.

\section{The objectives of the media policy:}

Table9. Clarifies the objectives of the media policy:

\begin{tabular}{|c|c|c|c|c|}
\hline $\begin{array}{l}\text { The objectives of the media policy of Palestinian } \\
\text { institutions: }\end{array}$ & SMA & $\begin{array}{l}\text { Standard } \\
\text { deviation }\end{array}$ & $\begin{array}{l}\text { Relative } \\
\text { weight }\end{array}$ & Arrangement \\
\hline National mobilization towards local issues. & 4.24 & 0.681 & 84.80 & 1 \\
\hline Protecting the historical and cultural heritage. & 4.13 & 0.693 & 82.60 & 2 \\
\hline Supporting peoples' causes and friendly countries. & 4.10 & 0.797 & 82.00 & 3 \\
\hline Meet the desires and needs of the readership. & 3.95 & 0.532 & 79.00 & 4 \\
\hline $\begin{array}{l}\text { Adopting the official position on foreign events and } \\
\text { issues. }\end{array}$ & 3.94 & 0.792 & 78.80 & 5 \\
\hline $\begin{array}{l}\text { Monitoring government performance and exercising a } \\
\text { critical role on this performance. }\end{array}$ & 3.89 & 0.831 & 77.80 & 6 \\
\hline $\begin{array}{l}\text { Supporting the trend towards supporting sustainable } \\
\text { development. }\end{array}$ & 3.87 & 0.805 & 77.40 & 7 \\
\hline $\begin{array}{l}\text { Supporting the trend towards modernization and } \\
\text { modernization. }\end{array}$ & 3.83 & 0.786 & 76.60 & 8 \\
\hline $\begin{array}{l}\text { Fulfilling the desires and needs of the owner of the } \\
\text { enterprise. }\end{array}$ & 3.82 & 0.713 & 76.40 & 9 \\
\hline $\begin{array}{l}\text { Meet the desires and needs of advertisers in the media } \\
\text { organization. }\end{array}$ & 3.78 & 0.730 & 75.60 & 10 \\
\hline $\begin{array}{l}\text { Supporting the party experience and democratic } \\
\text { development in Palestine. }\end{array}$ & 3.74 & 0.828 & 74.80 & 11 \\
\hline
\end{tabular}

The results show through the previous table that the highest objectives of the media policy of Palestinian media institutions according to their relative weight were. The first goal of the media policy is "national mobilization towards local issues." It came with a relative weight (84.80\%), which indicates that it has obtained a (large) degree of approval from the respondents. As for the second objective of the media policy, "protecting the historical and cultural heritage," it came with a relative weight $(82.60 \%)$, which indicates that That he had obtained a (large) degree of approval by the sample members The researchers attribute that to the political situation in which the Palestinian society lives, as the Palestinian society is still living in a state of liberation from the Israeli occupation, which naturally imposes on the community a continuous national mobilization towards the local issues in which it lives This result is consistent with the findings of Karim's study (2014) that $92 \%$ of the respondents see the two papers 'interest in supporting and adopting the issues of the Kurdish people in the Kurdistan region and the Kurdish question, and defending the historical national rights in Kurdistan. The final goal of the editorial policy is "to support the experience. Partisanship and democratic development in Palestine. "It came with a relative weight $(74.80 \%)$, which indicates that it has obtained a (large) degree of approval by the respondents. The researchers attribute this goal to being ranked last among the goals set by the media policy of institutions, namely: The unsuccessful experience of partisanship by the Palestinian parties, the stumbling of democratic development within Palestinian society, especially after the events that followed the 2006 elections, and the arrival of the Palestinian situation into a dark corridor of differences, divisions, and uniqueness of decisions by the various Palestinian parties.

\section{Factors affecting the media policy:}

Table10. Explains the factors affecting the media policy of institutions. The study sample:

\begin{tabular}{|l|r|r|r|r|}
\hline Factors affecting the policies of media institutions & SMA & $\begin{array}{l}\text { Standard } \\
\text { deviation }\end{array}$ & $\begin{array}{l}\text { Relative } \\
\text { weight }\end{array}$ & Arrangement \\
\hline Media work ethics and professional codes of honor. & 4.07 & 81.40 & 0.545 & 1 \\
\hline Owners of the means or shareholders in their ownership. & 4.06 & 81.20 & 0.610 & 2 \\
\hline
\end{tabular}




\begin{tabular}{|l|r|r|r|r|}
\hline $\begin{array}{l}\text { Available communication and information technology and } \\
\text { limits to its use. }\end{array}$ & 4.02 & 80.40 & 0.694 & 3 \\
\hline $\begin{array}{l}\text { Legal and legislative restrictions on practicing media } \\
\text { work. }\end{array}$ & 4.00 & 80.00 & 0.689 & 4 \\
\hline Community standards, values, and traditions & 3.94 & 78.80 & 0.532 & 5 \\
\hline Sources of funding for media institutions & 393 & 78.60 & 0.703 & 6 \\
\hline $\begin{array}{l}\text { The characteristics and personal characteristics of the } \\
\text { contact person }\end{array}$ & 3.80 & 76.00 & 0.581 & 7 \\
\hline The affiliation of the contact person prevailing economic & 3.76 & 75.20 & 0.601 & 8 \\
\hline $\begin{array}{l}\text { The degree of flexibility of the } \\
\text { system. }\end{array}$ & 3.70 & 74.00 & 0.661 & 9 \\
\hline News sources parties - & 3.58 & 71.60 & 0.798 & 10 \\
\hline $\begin{array}{l}\text { Pressure groups in society (political } \\
\text { businessmen). }\end{array}$ & 3.56 & 71.20 & 0.830 & 11 \\
\hline Work relationships and stress & 4.07 & 81.40 & 0.545 & 12 \\
\hline Factors affecting the policies of media institutions & & 0.623 & \\
\hline
\end{tabular}

It is evident from the previous table that $81.4 \%$ of the respondents believe that the first factor affecting the media policy is the ethics of media work and professional codes of honor, which indicates that he has obtained a (high) degree of approval by the sample members. The researchers attribute this to the fact that Palestinian media institutions live like other institutions and suffer from a state of Palestinian division, which made them operate under two different Palestinian regimes to the point of contradiction, and each institution can operate comfortably under the system that it tends to. This result is consistent with the findings of Hussein's study (2014), where $87 \%$ of the respondents believe that the most influential factors in editorial policy are the degree of freedom allowed by the political system, and the extent of the newspaper's management commitment to the ethics of journalism. As for the second factor affecting the media policy, it is the owners of the media or the shareholders in their ownership. "It came with a relative weight of $81.20 \%$, which indicates that it has obtained a (large) degree of approval by the sample members. The most important factors that affect the media policy, and then comes the role of owners of media outlets or shareholders in their ownership The researchers believe that it is logical that the owners or shareholders in ownership of them have a role in drawing the media policy of these institutions, because they did not create or support them except to express their views And their thoughts.

\section{Third: advertising revenues in media institutions and their relationship to media policy:}

\section{The contact person's view of the positive effects of advertising revenue on media policies}

Table11. Contact Person's Perception of the Positive Effects of Advertising Revenue on Media Policies:

\begin{tabular}{|l|r|r|r|r|}
\hline $\begin{array}{l}\text { The contact person's insight into the } \\
\text { positive impacts of ad revenue }\end{array}$ & \multicolumn{1}{|l|}{ SMA } & $\begin{array}{l}\text { Standard } \\
\text { deviation }\end{array}$ & $\begin{array}{l}\text { Relative } \\
\text { weight }\end{array}$ & Arrangement \\
\hline $\begin{array}{l}\text { Bringing advanced technology to facilitate } \\
\text { media work. }\end{array}$ & 4.11 & 0.879 & 82.20 & 1 \\
\hline $\begin{array}{l}\text { Achieving economic stability and increasing } \\
\text { the wages and rewards of editors and workers } \\
\text { of the media institution. }\end{array}$ & 4.03 & 0.978 & 20.60 & 2 \\
\hline $\begin{array}{l}\text { Providing the necessary financial support for } \\
\text { the administrative and editorial development } \\
\text { of the institution. }\end{array}$ & 3.96 & 0.605 & 79.20 & 3 \\
\hline $\begin{array}{l}\text { Preserving the independence of the institution } \\
\text { and ensuring its survival and continuity }\end{array}$ & 3.92 & 0.954 & 70 & \\
\hline $\begin{array}{l}\text { Providing the necessary funding to form a } \\
\text { network of correspondents in all parts. }\end{array}$ & 3.81 & 0.782 & 76.20 & 5 \\
\hline $\begin{array}{l}\text { Adding some weight to the organization as it } \\
\text { is widespread. }\end{array}$ & 3.67 & 0.814 & 73.40 & 6 \\
\hline Expansion of media activities. & 3.41 & 0.999 & 68.20 & \\
\hline
\end{tabular}

It is evident from the previous table that the first positive effect of advertisements according to the communicators is to bring advanced technology that helps in facilitating the media work, it came with a relative weight of $82.20 \%$, which indicates that it has obtained a (large) degree of approval by the sample members, and the researchers attribute this result To the great importance that technology has 
contributed to facilitating media work, by providing the appropriate equipment and devices for that, whether inside or outside the institution, and in order to be able to compete with other media that are fast and timely in transmitting events moment by moment, especially what social media has witnessed and the emergence of something. Known as citizen journalism.

The second vision of the contact person on the positive effects of the advertising institution's revenues is to "achieve economic stability and increase the wages and bonuses of editors and workers." It came with a relative weight $(82.20 \%)$, which indicates that it has obtained a (large) degree of approval by the sample members. The researchers believe that this vision is a basic requirement for any institution operating in any field and has different expenditures such as salaries for employees, equipment, equipment and other things. Therefore, those in charge of institutions seek to achieve the financial stability of the institution through the advertisements that it receives from advertisers, knowing that most of the workers in the institutions of the study sample do not receive state support, as happens in some countries of the world. This result is consistent with what the Poor's study found. And it was (2009AD) that the newspapers of the major chains tend to be associated with commercial and economic projects and investments that secure their economic influence, while this result differs with the findings of the Al-Shujairi study $(2012 \mathrm{CE})$, where it found that the main reliance of the newspapers that were subjected to the study is on different sources of financing According to the respondents' answers with government support, or a person or party in exchange for relying on advertisements and selling press services as an important source for the survival of the newspaper's publication, the results from the previous table show that the lowest perception of the contact person of the positive effects of advertising revenue on Media policies according to the relative weight were an increase in the media activities, as it came with a relative weight of $68.20 \%$, which indicates that it obtained a (large) degree of approval by sample members.

\section{The contact person's view of the negative impacts of the media's advertising revenue on policies Informational.}

Table12. Shows the communicator's vision of the negative impacts of advertisements

\begin{tabular}{|l|l|l|l|l|}
\hline $\begin{array}{l}\text { The contact's insight into the } \\
\text { negative impacts of ad revenue }\end{array}$ & SMA & $\begin{array}{l}\text { Standard } \\
\text { deviation }\end{array}$ & $\begin{array}{l}\text { Relative } \\
\text { weight }\end{array}$ & Arrangement \\
\hline $\begin{array}{l}\text { Giving great importance by the } \\
\text { administration to the task getting } \\
\text { advertisements at the expense of } \\
\text { media work }\end{array}$ & 3.06 & 0.964 & 61.20 & 1 \\
\hline $\begin{array}{l}\text { The tyranny of the advertising } \\
\text { material space over the media } \\
\text { content space. }\end{array}$ & 2.87 & 0.980 & 57.40 & 2 \\
\hline $\begin{array}{l}\text { Mixing advertising and } \\
\text { informational materials without } \\
\text { distinguishing them. }\end{array}$ & 2.85 & 0.998 & 57.00 & 3 \\
\hline $\begin{array}{l}\text { Posting advertisements may vary } \\
\text { with the media policy of the } \\
\text { institution }\end{array}$ & 2.71 & 0.920 & 54.20 & 4 \\
\hline $\begin{array}{l}\text { Advertisers sometimes intervened to } \\
\text { direct the institution's media policy. }\end{array}$ & 2.69 & 0.915 & 53.80 & 6 \\
\hline $\begin{array}{l}\text { The media organization lost its } \\
\text { credibility for publishing sometimes } \\
\text { misleading ads. }\end{array}$ & 2.49 & 0.969 & 49.80 & \\
\hline $\begin{array}{l}\text { Some callers receive revenue from } \\
\text { advertisers for posting specific ads. }\end{array}$ & 2.46 & 0.988 & 49.20 & \\
\hline
\end{tabular}

The results show through the previous table that the highest visibility of the contact person of the negative impacts of the media organization's advertising revenues on media policies according to the relative weight was that the administration gave great importance to the task of bringing advertisements at the expense of media work, it came with a relative weight (61.20\%), which indicates However, he obtained a degree of approval (average) by the sample members The researchers attribute this result to the fact that one of the main objectives is to provide the financial return to the institution through which it can provide the various expenses of the workers, and to provide operational expenses, especially when the institutions are in a state of competition, and what It has been linked to the 
technological development of the media, and this result is consistent with the findings of the study of Lacey and Alice (1996 AD), which concluded that the growth of chains and journalistic monopolies and the associated separation between ownership and management, and the weakness of control and control by owners over these projects led to an increase in interest in the gains Profits are at the expense of the press service.

As for the second vision of the contact person of the negative effects of the advertising institution's revenues, the tyranny of the advertising material's area over the content area came with a relative weight of (57.40\%), which indicates that he has obtained a (average) degree of approval by the sample members. As a result of what was preceded by the institutions' efforts to expand the advertising space, in order to cover their expenses, and this expansion comes at the expense of the media material, and not far from the rest of the other options from the negative effects that are reflected on the organization due to reliance on advertisements, and the confusion between the advertising material and the media material, and interference Advertisers sometimes in the media policy, some contact persons receive a monetary return from advertisers for publishing certain ads, and the institution loses its credibility for presenting misleading ads sometimes.

\section{From the point of view of the contact person, the most important problems resulting from the multiplicity of media ownership.}

Table13. Shows the frequency and percentage of the most important problems resulting from the multiple types of media ownership:

\begin{tabular}{|l|r|r|r|}
\hline $\begin{array}{l}\text { The most important problems arising from the } \\
\text { multiplicity of ownership types }\end{array}$ & Number & Percentage \% & Arrangement \\
\hline $\begin{array}{l}\text { The creditors' guarantee in the sole proprietorship is } \\
\text { limited to the properties of the project owner, which } \\
\text { may expose their money to be lost if the project fails. }\end{array}$ & 55 & 44.7 & \\
\hline $\begin{array}{l}\text { In the pattern of ownership of solidarity companies, } \\
\text { if one of the partners makes a mistake, then the rest } \\
\text { of the partners bear this mistake }\end{array}$ & 52 & 42.3 & \\
\hline $\begin{array}{l}\text { The family ownership negatively affects the } \\
\text { development of the journal, as its inheritors did not } \\
\text { make the effort as the parents did when it was started }\end{array}$ & 48 & 39.0 & \\
\hline $\begin{array}{l}\text { The pattern of corporate ownership is not able to } \\
\text { provide the appropriate climate, which achieves job } \\
\text { security for editors, through recruitment processes, or } \\
\text { the establishment of regulations defining work } \\
\text { relationships }\end{array}$ & 43 & & 3 \\
\hline $\begin{array}{l}\text { In the pattern of ownership of joint-stock companies, } \\
\text { it may occur as a result of misconduct by } \\
\text { management, and an increase in the extravagance of } \\
\text { expenses }\end{array}$ & 39 & & \\
\hline Other & 2 & & \\
\hline Total & 239 & & \\
\hline
\end{tabular}

- $\quad$ Multiple choice answers have been calculated from 123

It was found from the previous table that $44.7 \%$ of the study sample considered the most important problems resulting from the multiplicity of types of journalistic ownership, which is the creditors 'guarantee in individual ownership that is limited to the project's owner's property, which may expose their money to loss if the project fails. The researchers attribute this to the correlation of ownership of the institution with individual ownership, which allows the owner to freely dispose of its management and money. And $42.3 \%$ consider it in the pattern of ownership of solidarity companies. If one of the partners makes a mistake, then the rest of the partners bear this mistake, and 39.0\% consider it negatively affecting the family's ownership in the development of the journal since its heirs did not make an effort as the parents did at the start of its establishment, and a rate of 35.0\% They consider that the pattern of corporate ownership is unable to provide the appropriate climate, which achieves job security for editors, through appointment processes, or by setting regulations that define work relationships, and what $31.7 \%$ consider them to be in the ownership pattern of Contributed company may occur as a result of misbehavior by management, increased wastefulness In expenditures, and a rate of $1.6 \%$, that there are other effects. 


\section{The most important proposals for not reflecting the ownership pattern on the media policy:}

Table14. Shows the frequency and percentage of your most important proposals because the ownership style does not reflect on editorial policy.

\begin{tabular}{|l|r|r|r|}
\hline $\begin{array}{l}\text { The most important suggestions for not } \\
\text { reflecting the ownership pattern on media } \\
\text { policy }\end{array}$ & Number & Percentage \% & Arrangement \\
\hline $\begin{array}{l}\text { Imposing a binding media policy that defines } \\
\text { the nature of the advertiser's relationship with } \\
\text { media leaders }\end{array}$ & 89 & 72.4 & 1 \\
\hline $\begin{array}{l}\text { Issuing a media honor charter that regulates the } \\
\text { performance of the Palestinian media, and sets } \\
\text { professional and ethical controls, as well as } \\
\text { deterrent sanctions that are strictly and equally } \\
\text { applied to all violators }\end{array}$ & 84 & 68.3 & \\
\hline $\begin{array}{l}\text { Issuing laws that guarantee the separation of } \\
\text { management from capital in media institutions, } \\
\text { in order to ensure protection and legal and } \\
\text { union support for media professionals }\end{array}$ & 77 & 62.6 & \\
\hline $\begin{array}{l}\text { Announcing the media policy, and periodically } \\
\text { disclosing sources of income and financing }\end{array}$ & 77 & & \\
\hline $\begin{array}{l}\text { Take all measures to break the monopoly of a } \\
\text { limited number of advertising companies on the } \\
\text { proceeds of advertisements in various media } \\
\text { institutions and direct the institution's policy in } \\
\text { line with its advertising policy }\end{array}$ & 62 & 50.4 & \\
\hline Total & & & \\
\hline
\end{tabular}

- Multiple choice answers have been calculated from 123.

It was found from the previous table that $72.4 \%$ of the study sample consider their most important proposals for the lack of a reflection of the ownership pattern on media policy to impose a binding policy that defines the nature of the advertiser's relationship with media leaders, and $68.3 \%$ consider issuing a media honor charter that regulates the performance of the Palestinian media and establishes professional and ethical controls Deterrent penalties are applied firmly and equitably to all violators, and 62.6\% consider issuing laws guaranteeing the separation of management from capital in media institutions, in a manner that guarantees protection and legal and union support for media professionals, and $62.6 \%$ consider announcing the media policy, and the periodic disclosure of income sources And financing, and 50.4\% consider taking all measures to break the monopoly of a limited number of advertising companies on the proceeds of advertisements in various institutions and directing the institutions' policy in line with their advertising policy. The researchers attribute the previous results to that workers in media institutions seek to work in a work environment that is clearly defined, and their work is not related to the views or whims of those at the head of the business or the owners of the institution, and the work is on a clear ground, and this is ensured by creating a media honor charter To act as a organizer for the Palestinian media work.

- The second requirement: the most important results of the study and recommendations

1. The study showed that $35 \%$ of the study sample work in media outlets with corporate ownership, and $26.8 \%$ are party or political movement ownership.

2. The study showed that $58.5 \%$ of the study sample prefer the form of contributed company to own the media institution

3. The study indicated that $40 \%$ of the study sample believed that the most important conditions for the owner of a media institution is to have knowledge of the media industry and its technologies.

4. The study confirmed that $38.9 \%$ of the study sample believe that the necessary conditions that must be met by the owner of a media institution to be professional.

5. The study showed that the form of intervention of the owners of media institutions in the media policy is that the owner only defines general guidelines and principles that cannot be crossed. It was ranked first with a relative weight (77.40\%) and obtained a (large) degree of approval by the sample members. 
6. The study showed that $51.2 \%$ of the study sample depend on funding from advertising and marketing, and then self-support for it.

7. The study clarified that $51.2 \%$ of the study sample do not know whether the media institution in which they work is getting financial support from various parties.

8. The study clarified that $35.8 \%$ of the study sample believed that the concept of media policy they have is a set of principles, rules and guidelines that control the style and the way in which the media content is presented.

9. The study showed that the highest goals of the media policy of Palestinian media institutions are national mobilization towards local issues. It came with a relative weight $(84.80 \%)$, with a (large) degree of approval from individuals.

10. The study indicated that $81.4 \%$ of the respondents believe that the most influencing factor on the media policy "is the ethics of media work and professional codes of honor, and it obtained a (large) degree of approval by the respondents.

11. The study showed that the first positive effect of advertisements according to the communicators is to bring advanced technology that helps in facilitating the media work, and it came with a relative weight of $82.20 \%$, and it obtained a (large) degree of approval from the respondents.

12. The study showed that the highest negative effects of the media institution's revenues from advertising activity on media policies, bringing advertisements at the expense of media work, came with a relative weight $(61.20 \%)$, and it obtained a degree of approval (medium) by the sample members.

13. The study showed that $44.7 \%$ of the study sample considered the most important problems resulting from the multiplicity of types of journalistic ownership, which is the creditors 'guarantee in individual ownership that is limited to the project's property, which could expose their money to loss if the project fails.

14. The study showed that $72.4 \%$ of the study sample considered their most important proposals for the lack of a reflection of the ownership pattern on the media policy, imposing a binding policy that defines the nature of the advertiser's relationship with media leaders in Palestinian media institutions.

15. The study emphasized that the introduction of a clear ownership system guarantees the transparency of the media institution, and avoids it falling under the influence of the various interactions that may occur between those in charge of the institution.

\section{- Study recommendations:}

1. Creating legislation to regulate the relationship between the owners of media institutions and those who contact them, and formulating media policy in a way that does not conflict with the interests of Palestinian society.

2. Balancing the various objectives of the media policies of Palestinian institutions, in a way that achieves the public interest of media institutions and society.

3. Encouraging media institutions to provide financial resources that would bring them stability and ensure their survival and ability to face crises.

4. Supporting the positive effects of advertisements, and helping to weave a clear relationship based on professional rules that ensure a balance between meeting the needs of the institution and carrying out community functions.

5. A balance between media and advertising content in a way that does not affect the nature of media work.

6. Issuing a media honor charter that organizes the performance of the Palestinian media, and establishes professional and ethical controls, especially with regard to ownership and its relationship with the media policy of Palestinian institutions.

7. Periodic disclosure of sources of income and funding for Palestinian media institution, to ensure transparency and integrity in the media work in the Palestinian society. 


\section{RESOURCES AND REFERENCES}

[1] Ibrahim, Yasser (2016). The Effect of Press Advertising on Newspapers' Editorial Policy: A Field Study on Al-Attiba and Al-Independent Newspapers. Khartoum.

[2] Bushra, Ikram (2017). Editorial policy and its implications for news production: an applied analytical study on Omdurman National Radio, (unpublished PhD thesis) Sudan University of Science and Technology, Khartoum.

[3] Ben Muraishid, Khadija (2009). The effect of advertisement material in Saudi newspapers on the professional performance of journalists, (unpublished master thesis) King Saud University, Saudi Arabia.

[4] Thabet, Muhammad (2017). The management of Palestinian press institutions during the crisis of the Israeli aggression on Gaza in 2014, and its reflection on professional performance (unpublished MA study) Gaza: The Islamic University ..

[5] Hijab, Muhammad (2010) Theories of Communication, 1st Edition. Cairo: Dar Al-Fajr for Publishing and Distribution.

[6] Hussein, Ahmad (1999). Ownership and The Theory of Contract in Islamic Law, i 1. Cairo: Arab Publishing and Distribution House.

[7] Hussein, Zuhair (2014). The Editorial Policies of Gulf Newspapers and the Factors Affecting the Contact Person, Field Study, Semat Magazine, Volume (4), Issue (1), pp. 65-97.

[8] Hussein, Samir (1995). Media Research, 1st Edition, Cairo: The World of Books.

[9] . Rabee ', Abdel-Gawad (2008). The relationship between the pattern of ownership of Egyptian newspapers and freedom of expression, a paper presented to the fourteenth annual scientific conference of the Faculty of Mass Communication, Cairo: Cairo University.

[10] Al-Shujairi, Siham (2012). Newspaper financing and its implications for editorial policy. A field study on the contact person, Journal of the College of Arts. Issue (100) p. 347-389.

[11] Al-Shakhanbeh, Ziyad (2012). The editorial policy trends of the Jordanian daily press vis-à-vis the popular movement: an analytical study of Al-Rai and Al-Arab Al-Youm newspapers (unpublished master's thesis) Yarmouk University, Amman.

[12] Guest, Adel (1997). Editorial policy of foreign pages in Egyptian daily newspapers (unpublished $\mathrm{PhD}$ study). Cairo: Zagazig University.

[13] Abdel-Rahman, Abdel-Rahman (2011). The relationship between media ownership and its treatment of democratic transition and political decision-making issues.

[14] Abdel-Ati, Alaa (2006). The effect of the ownership pattern in Arab satellite television news channels on their political function. Paper presented to the conference on specific education and its role in human development in the era of globalization, Mansoura: Mansoura University.

[15] Abdel-Majeed, Leila and Alameddine, Mahmoud (2009). The art of press editing, i 1. Cairo: Arab Publishing House.

[16] Ghaly, Mahrez. (2009). Managing press institutions and their economics in the contemporary world. I 1. Cairo: House of the Arab World

[17] Al-Fatafta, Mahmoud (2013). The editorial policy in Palestinian newspapers and its impact on freedom of expression. Ramallah: Palestinian Center for Development and Media Freedoms.

[18] Al-Fawal, Nagwa (1995). Read on contact person studies. The National Social Journal.

[19] Al-Fayrouzabadi, Majd al-Din Muhammad Ibn Ya'qub, The Dictionary of the Ocean Beirut: Dar Al-Jalil, B-T).

[20] Karim, Ismail (2014). The Impact of Administrative Factors on the Editorial Policy in Kurdish Newspapers, (Unpublished Master Thesis) Mansoura University, Mansoura

[21] Lama, Heba (2011). The editorial policy of Al-Hura and Sawa is in the service of American foreign policy. Birzeit.

[22] Muhammad, Muhammad Sayed (1979) Media Economics, 1st Edition. Cairo, Al-Khanji Library.

[23] Makhlouf, Ghada (2015). The advertising's contribution to shaping the politics of Libyan newspapers. (A magister message that is not published). Benghazi University, Benghazi.

[24] Irons, Hassan and Mr. Leila. (2012). Communication and its contemporary theories. I 10. Cairo: The Egyptian Lebanese House.

[25] Merle, John, and Lowenstein, Ralph. Media is a means and a message, Arabization: Dr. Saed Khader AlOrabi Al-Harithi. Riyadh: House of Mars, 1409 A.H. - 1989 A.D.

[26] . Al-Yafei, Awatef (2010). Factors affecting building the agenda of the Yemeni press, an analytical and field study (unpublished master's thesis). Cairo University, Cairo. 
[27] Yunus, Abdullah Mukhtar (1987). Ownership in Islamic law and its role in the Islamic economy. I 1. Alexandria: University Youth Foundation.

\section{- Third: foreign references}

1. Adesoj ‘A. O. \& Hahn ‘H. P. (2011). When (not) to be proprietor: Nigerian newspaper ownership in a change polity. African study monographs ،32(4): 177-203

2. Cohen ‘ $\mathrm{N} \&$ Macdonald 'S. (2011). Making media public: from discussion to action. Canadian journal of communication ‘vo36،2011.

3. Lacy ‘S. Shaver ‘M. A. \& Cyr ‘C. S. (1996). The effects of public ownership and newspaper competition on the financial Performance Of newspaper Corporations: A replication and extension. Journalism \& Mass communication Quarterly ،73(2) ، 332.341.

4. Ohlsson ‘J. (2010). The practice of newspaper ownership: fifty year of control and influence in the Swedish local press ‘ $\mathrm{PhD}$ ،University of Gothenburg. Retrieved from www. All academic. com.

5. Picard 'R. G. van Weezel 'A. (2011). Capital and control: consequences of different forms of newspaper ownership. Media management and economics division 'Association for Education in Journalism and Mass Communication conference. AEJMC 2011 ravailable at: www. allacademic. com.

6. Powers ‘A. \& An ‘S. (2009). The effects of ownership structure in news coverage in the united state. Observatorio $\left(\mathrm{OBS}^{*}\right)$ ، 2009 3.1.

\section{Fourth: Interviews:}

1. Tawfiq Salim, head of the Palestinian Media Group (interview: February 22, 2019). Rami Khreis, managing editor of Al-Risala newspaper (interview: February 21, 2019)

2. Muhammad Yaseen, journalist, and former editor-in-chief of Palestine Newspaper (20 Interviews: 14 February 2019 AD)

Citation: Dr. Amin Mansour Wafi, Mr. Hussein M .F. AbouMddan. "Ownership Patterns of Palestinian Media and Its Influence on Media Policy". International Journal of Media, Journalism and Mass Communications (IJMJMC), vol 7, no. 1, 2021, pp. 14-32 doi: http://dx.doi.org/10.20431/2454-9479.0701004.

Copyright: () 2021 Authors. This is an open-access article distributed under the terms of the Creative Commons Attribution License, which permits unrestricted use, distribution, and reproduction in any medium, provided the original author and source are credited. 